\title{
MERCADO DE SERVIÇOS PESSOAIS: UMA ANÁLISE ANTROPOLÓGICA DAS TÉCNICAS GERENCIAIS E SUA RELAÇÃO COM A INTIMIDADE
}

\author{
Personal services market: an anthropological analysis of managerial techniques \\ and their relation to intimacy
}

Maria Luisa Célia Escalona de Dios'

\begin{abstract}
Resumo
O propósito do artigo é apresentar uma discussão sobre como técnicas gerenciais e rituais se entrelaçam na atuação de consultores pessoais. $O$ trabalho fundamenta-se em uma pesquisa etnográfica que teve como objeto de estudo um mercado de serviços pessoais que assumem a forma de consultorias. Os prestadores de serviço que nele atuam autodenominam-se personal, enfatizando a natureza personalizada (individualizada) dos serviços oferecidos. Os processos de consultoria relatados mostram formas de atuação que apagam as fronteiras entre as dimensões mágica e empresarial. Também evidenciam como as técnicas gerenciais permeiam a intimidade dos clientes dos personals. Em outras palavras, estes consultores pessoais são mediadores culturais que de diversas formas levam a linguagem gerencial para dentro da intimidade de seus clientes. O texto se insere na perspectiva da sociologia da gestão e das técnicas gerenciais.
\end{abstract}

Palavras-chave: Rituais; Técnicas gerenciais; Serviços pessoais; Consultorias pessoais; gerenciamento de si.

\begin{abstract}
The purpose of this paper is to present a discussion on how management techniques and rituals intertwine in the performance of personal consultants. The work is based on an ethnographic research that had as its object of study a market of personal services that take the form of consultancies. The service providers who work in it call themselves personal, emphasizing the personalized (individualized) nature of the services offered. The reported consulting processes show ways of acting that blur the boundaries between the magic and business dimensions. They also show how management techniques permeate the intimacy of personals clients. In other words, these personal consultants are cultural mediators who in many ways take management language into the privacy of their clients. The text fits into the perspective of management sociology and management techniques.
\end{abstract}

Keywords: Rituals; Management techniques; Personal services; Personal consulting; Selfmanagement.

\footnotetext{
1 Mestre em Antropologia pela UFRGS. Doutora em Ciências Sociais pela PUC/RS e pósdoutorado em andamento em Ciências Sociais da PUC/RS. E-mail: mldios@outlook.com Cidade: Porto Alegre. Agradeço a CAPES pelo apoio durante a realização do doutorado.
} 
Mercado de serviços pessoais: uma análise antropológica das técnicas gerenciais e sua relação com a intimidade | Maria Luisa Célia Escalona de Dios

\section{Introdução}

O artigo traz uma discussão sobre como as técnicas gerenciais são utilizadas por consultores pessoais, como elas se mesclam com rituais na atuação destes profissionais, e são utilizadas pelos clientes para o gerenciamento de si. Em suma, uma análise antropológica das técnicas gerenciais e sua relação com a intimidade. As técnicas gerenciais são indicadores, planos estratégicos, métodos para elaboração de metas, planos de marketing, de comunicação, planos de qualidade total, sistemas de gestão do cliente, ou seja, toda a gama de procedimentos gerenciais que servem para coordenar a ação organizacional para controlar os seus resultados (CHIAPELLO; GILBERT, 2013). Este artigo é o resultado de uma pesquisa etnográfica realizada em Porto Alegre e São Paulo, entre os anos de 2013 a 2017, a partir da qual realizei observação direta, acompanhei suas atividades e entrevistei alguns profissionais desta modalidade de prestação serviços. Sobre meus interlocutores, optei por alterar os seus nomes no decorrer do texto para preservar suas identidades. Os prestadores de serviço que nele atuam autodenominam-se personal, enfatizando a natureza individualizada dos serviços oferecidos e, por deterem um saber específico, apresentam-se como especialistas. Ao longo da pesquisa, foram identificados uma miriade de diferentes tipos de personals. Os seis personals com os quais tive acesso mais profundo e longo, ou seja, entrevistas e observação foram: Dora personal organizer (especialista em organização de ambientes), Marta personal stylist (especialista em consultoria de estilo), Amadeu personal dog walker (cuidador e passeador de cachorros), Eduardo personal trainer (especialista e professor particular de educação física), Madalena personal friend (acompanhante de senhoras para eventos sociais, nos quais assume o papel de amiga de longa data) e Alexandre personal xamã (guru ou guia espiritual). Os personals prestam serviços que não podem ser alienados da sua pessoa, a relação com os clientes é de proximidade, circulando o afeto e a empatia. No entanto, ao mesmo tempo é uma relação comercial, pois está se vendendo um serviço especializado e ajustado às demandas dos clientes. 
Mercado de serviços pessoais: uma análise antropológica das técnicas gerenciais e sua relação com a intimidade | Maria Luisa Célia Escalona de Dios

Nos dias de hoje a gestão é onipresente. Ela se disseminou das grandes empresas privadas para a esfera pública, Organizações Não Governamentais (ONG's), sindicatos, pequenas e médias empresas e por uma gama de países. A gestão gradualmente se impõe a todas as organizações, como um modelo a ser seguido e ao qual todos devem se alinhar. Para Boussard (2008) a gestão é um discurso que se formou no século XIX e se baseia no logos da gestão que está fundado em três principios: domínio, desempenho e racionalidade, em conjunto, com as técnicas de gestão elaboradas conforme os contextos institucionais. Detalhando os três principios: o domínio é exercido pelo controle imposto pela organização; o desempenho é o seu objetivo e a racionalidade a sua maneira de agir. Para a autora a gestão quase não cumpre suas promessas em termos de controle, desempenho e racionalidade e se impôs de modo hegemônico pela crença em sua eficácia compartilhada e mantida por quem faz a faz, que são os gerentes ou gestores, consultores e acadêmicos de administração de empresas. O desenvolvimento da gestão está ligado ao desenvolvimento do capitalismo industrial e a ciência. Ao longo dos anos o aperfeiçoamento da e a sua aplicação por meio das suas técnicas gestão foram substituindo os controles feitos pelas pessoas (chefes, supervisores) por um controle invisivel dessas técnicas interiorizadas pelos empregados, ou seja, o controle se torna, paulatinamente, invisivel. O funcionamento das empresas é baseado na racionalidade e no cálculo de previsões dos resultados. Assim, a impessoalidade transforma os antigos laços pessoais no trabalho em laços de subordinação a regra (BOUSARD, 2008, p. 66). A gestão e as suas técnicas se difundiram depois da Segunda Guerra Mundial por meio do Plano Marshall (BOLTANSKI, 1982) e avançou com a internacionalização das empresas. As técnicas de gestão atuam como uma linguagem comum aos empregados das empresas internacionalizadas. Desta forma os fornecedores e terceirizados também as adotam. O discurso da gestão e suas técnicas são difundidos como, isentos, objetivos, imparciais e desta maneira a gestão e suas técnicas são tidos como virtuosos. No entanto, a gestão e suas técnicas são manipuladas pelos diretores e gerentes de 
Mercado de serviços pessoais: uma análise antropológica das técnicas gerenciais e sua relação com a intimidade | Maria Luisa Célia Escalona de Dios

acordo com o contexto em que a organização se encontra, sempre na direção da lucratividade em detrimento das pessoas envolvidas. O discurso de gestão virtuoso camufla as dinâmicas de dominação (BOUSSARD, 2008).

Por sua vez Gaulejac (2007) faz uma reflexão sobre a gestão, como uma ideologia, transformada em uma tecnologia de poder. Ideologia que é difundida pelos recursos humanos das empresas sob a égide do desenvolvimento profissional, visando a excelência. Ele sustenta que por um lado ela tende mais do que nunca a considerar o ser humano não como sujeito, mas como objeto - um recurso humano -, ou seja, um capital que convém tornar produtivo (p. 28) -, exigindo dele um engajamento intenso na busca por um desempenho exitoso no trabalho. Por outro lado, a ideologia gerencial vai além da estrutura da empresa privada para se impor em todas as nossas instituições e, finalmente, em toda a sociedade, correndo o risco de deixá-la "doente", como revelam certos sintomas preocupantes, como aumento de colapsos nervosos, crescimento de fenômenos de estresse ou mesmo esgotamento. Gaulejac (2007, p. 29) não é contra a gestão, desde que ela melhore as relações humanas e a vida social. Para ele é legitimo organizar o mundo, racionalizar a produção, preocupar-se com a rentabilidade. Ele critica o uso que se faz dela como tecnologia de poder. A ideologia gerencial visa mobilizar as subjetividades das pessoas para adequar os indivíduos a serem mais inovadores, empreendedores, autônomos, criativos, saiba correr riscos e assumam a responsabilidade pelo seu desenvolvimento. Dito de outra forma, a ideologia gerencial visa tornar os indivíduos aptos para fazerem parte do terceiro "espírito do capitalismo" (BOLTANSKI e CHIAPELLO, 2009). Assim, indivíduos mais flexiveis, trabalhando de forma autônoma, mas em equipe, navegando de um projeto ao outro numa dinâmica de rede e tendo a capacidade de se adaptar para trabalhar com pessoais diferentes, ou seja, um indivíduo da cité dos projetos, como enunciam Boltanski e Chiapello (2009).

As técnicas de gestão são aqui entendidas no sentido conferido por Mauss (2003), logo são construções sociais condicionadas por fatores históricos, socioeconômicos, culturais e políticos. Ele explica em seu ensaio 
Mercado de serviços pessoais: uma análise antropológica das técnicas gerenciais e sua relação com a intimidade | Maria Luisa Célia Escalona de Dios

sobre as técnicas corporais, que elas são as maneiras pelas quais as pessoas sabem fazer uso do ser corpo, de forma tradicional, em cada sociedade, como os atos de correr, nadar e caminhar. E que estes atos não são naturais, são socialmente construídos e diferem de uma sociedade a outra.

As técnicas podem ser materiais (técnicas de artesanato, de produção, etc.) e imateriais, sendo estas últimas têm a sua origem na magia. Como exemplos de técnicas imateriais, nos dias de hoje, temos as psicoterapias, técnicas de comunicação, técnicas de planejamento e técnicas de gestão. As técnicas de gestão se aplicam as relações humanas, procurando coordená-las, formatando as ações das pessoas e assim uniformizando as ações e buscando obter resultados que possam ser comparados entre colegas de trabalho, as áreas de uma empresa, entre empresas e entre países. As técnicas imateriais como as técnicas de gestão se caracterizam pela incerteza de seus resultados e a sua função varia dependendo do contexto que são aplicadas (CHIAPELLO e GILBERT, 2013).

As principais ideias abordadas no artigo mostram como na sua atuação os personals utilizam técnicas gerenciais junto aos clientes, trazendo o relato de quatro personals. Inicialmente, trago os relatos de dois prestadores de serviços pessoais - Dora, personal organizer, e Alexandre, personal xamã -, pois nas suas atuações junto aos clientes se evidencia com mais clareza o entrelaçamento das técnicas gerenciais e dos rituais. Cada caso relatado dá ênfase a uma questão, logo, a personal organizer conduz a sua consultoria em forma de ritual, e o personal xamã dirige seu ritual por meio de técnicas gerenciais. Procuro mostrar que as metodologias utilizadas tanto por Dora como Alexandre, no atendimento aos seus clientes, esmaecem os limites entre as dimensões mágica e empresarial. Na sequência abordo como Eduardo, personal trainer e Marta, personal stylist utilizam as tecnologias gerenciais nas suas consultorias. O primeiro com o objetivo de engajar os clientes e a segunda para identificar pontos negativos e positivos sobre o tipo físico e estilo de vestir de seus clientes. 
Mercado de serviços pessoais: uma análise antropológica das técnicas gerenciais e sua relação com a intimidade | Maria Luisa Célia Escalona de Dios

\section{O mercado de consultorias pessoais}

Embora, num primeiro olhar, possa parecer que a multiplicação da atividade sob a denominação de personal seja fruto de algum modismo, depreendi ao longo da pesquisa, que ela é o resultado de um processo histórico. Consequência das transformações econômico-produtivas que se delinearam nos EUA e Europa nos anos sessenta e no Brasil a partir do final da década de oitenta. Assim, processos produtivos e administrativos passaram por consideráveis modificações relacionadas a automação - na área produtiva e administrativa - que, por sua vez, aumentaram tanto a produção dos mais diversos produtos manufaturados, como dos controles administrativos em detrimento da diminuição do número de empregos no chão de fábrica e na área de gestão. Durante a segunda metade da década de 1990, no Brasil, vários postos de trabalho de nível gerencial foram eliminados devido às reestruturações organizacionais (downsizing e reengenharia) nas empresas brasileiras, sendo que, profissionais graduados e com especialização ficaram à deriva no mercado, com uma situação profissional incerta (RIFKIN, 1995; ANTUNES, 2000; ALVES, 2009).

No início da década de 1990, o governo brasileiro iniciou o processo de abertura comercial, ou seja, muitos produtos estrangeiros tiveram uma redução nas tarifas aduaneiras o que facilitou a importação dos mais variados produtos. Então, diante dessa realidade, os produtos da indústria nacional passaram a concorrer com produtos muito baratos vindos de outros países, em especial do continente asiático, pois estes, ao contrário do Brasil, tinham baixos custos com empregados, impostos e taxas. Fato que ocasionou o fechamento de muitas empresas e consequentes altas taxas de desemprego Desta forma, para que as grandes e médias empresas brasileiras pudessem num primeiro momento sobreviver e numa segunda etapa tornarem-se competitivas em relação aos produtos importados, começaram a reestruturar tanto a sua configuração organizacional como o parque fabril, tendo em vista a redução das tarifas de importação de máquinas e equipamentos industriais (ALVES, 2009; ANTUNES, 2009; TESSARI, 2001). 
Mercado de serviços pessoais: uma análise antropológica das técnicas gerenciais e sua relação com a intimidade | Maria Luisa Célia Escalona de Dios

Em relação à conjuntura econômica, os governos da década de noventa deram ênfase a estabilização da economia pelo viés das políticas neoliberais, promovendo desregulamentações, priorizando as privatizações e diminuindo a intervenção do Estado na economia (ALVES, 2009; ANTUNES, 1995, 2009). Ao mesmo tempo, a ideologia do empreendedorismo começava a se entranhar na realidade brasileira por meio de cursos, palestras, vídeos e literatura difundidos pelo SEBRAE, além dos livros de Fernando Dolabela tido como o primeiro autor brasileiro especializado em empreendedorismo (MELO, 2008). No contexto empresarial as grandes e médias corporações privadas começaram vender parte de seu patrimônio e a realizar fusões entre si, o que acarretou mais demissões. Por sua vez, em meados da década de noventa surgem os planos para redução do quadro de pessoal, ou seja, o Plano de Demissão Voluntária (PDV) e o Plano de Aposentadoria Incentivada (PAI) que foram instrumentos ${ }^{2}$ utilizados tanto pelas empresas particulares quanto pelas públicas como forma de minimizar ações trabalhistas tanto por parte dos sindicatos como por parte dos demitidos (ALVES, 2009; ANTUNES, 2009). Nesse contexto, a transformação foi inédita e provocada com anuência do Estado (Governo Federal) não só com a redução das taxas de importação citadas anteriormente, mas, principalmente, ao promulgar leis que favoreceram a terceirização ${ }^{3}$. Assim a legislação sobre terceirização que iniciou no governo Collor foi avançando e se consolidando nos demais governos até os dias atuais. Concomitantemente, as grandes empresas iniciaram um amplo processo de terceirização daquelas atividades que não eram consideradas principais pela direção da empresa e nem pelos acionistas.

Sincronicamente, a intensificação da automação nos processos produtivos e a implementação de softwares de gestão, foram adotadas pelas

\footnotetext{
2 Os referidos planos conferiam aos optantes vantagens financeiras acima dos valores de uma simples demissão ou aposentadoria, em média os optantes do PDV ou PAI ganhavam uma indenização equivalente a dois ou três anos de salário, incluindo férias e décimo terceiro, além dos valores de praxe de uma demissão. Além de incluírem outros beneficios, especialmente para gerentes e diretores, tais como assistência de empresas de recolocação, manutenção de um até dois anos do plano de saúde e cursos de capacitação. Fonte: relatos dos informantes.

${ }^{3}$ De acordo com Leiria e Saratt (1995), o termo terceirização é uma especificidade brasileira, sendo que o neologismo foi criado pelo superintendente da Riocell (empresa gaúcha de celulose) Aldo Sani nos anos setenta que identifica a relação entre duas empresas em que uma delas presta serviços a outra. Como sinônimo de terceirização existe a palavra subcontratação.
} 
Mercado de serviços pessoais: uma análise antropológica das técnicas gerenciais e sua relação com a intimidade | Maria Luisa Célia Escalona de Dios

empresas tecnologias gerenciais como a reengenharia e o método Toyota de gestão que visavam modificar o método de gestão vigente, ou seja, a burocracia racional (WEBER, 1982) que orientava-se para a disciplina, o controle centralizados, vários níveis hierárquicos, divisão de tarefas intensamente especializadas que era refletida nos modelos fordista e taylorista. Por sua vez o toyotismo e a reengenharia orientam-se para uma gestão dita flexível, com funcionários polivalentes e adaptáveis as circunstâncias, processos enxutos, poucos niveis hierárquicos e controle descentralizado (HARVEY, 2003; SENNETT, 2006; 2006a). Assim, com a implementação da reengenharia, as empresas eliminaram muitas funções intermediárias ou gerenciais compostas por funcionários graduados e com especialização, substituídos por softwares de gestão e por empresas terceirizadas. Juntamente com as tecnologias gerenciais citadas apareceram no cenário empresarial as empresas de consultoria que absorveram parte dos gerentes dispensados das grandes corporações (DONADONE, 2001). As empresas de consultoria foram responsáveis por auxiliar a implementar a reengenharia, colocar em prática os softwares de gestão, conduzir as fusões entre as empresas e as terceirizações para tornar estas mais enxutas, flexiveis e lucrativas (ANTUNES, 2009; HARVEY, 2003; RIFKIN, 1995; SENNETT, 2006; 2006a).

Todo esse processo teve como resultado a flexibilização do trabalho gerando condições de insegurança e incerteza profissional. Assim desde a década de 1990 o Brasil vem adotando uma série de politicas neoliberais, ou seja, um conjunto de políticas públicas orientados para baixar impostos, reduzir barreiras comerciais, reduzir gastos sociais, terceirização e desregulamentação do mercado de trabalho. Além disso, desde o final da década de 1990 até 2014, ocorreu um crescimento do poder econômico da população brasileira, um relativo aumento no grau de mobilidade social e, também, uma sofisticação no padrão de consumo.

No Brasil, o crescimento deste mercado de serviços pessoais aconteceu entre 2004 e 20144. Pode-se argumentar que os personals

\footnotetext{
4 Dado obtido de forma empírica pela pesquisadora que monitora esse tipo de serviço desde 2008.
} 
Mercado de serviços pessoais: uma análise antropológica das técnicas gerenciais e sua relação com a intimidade | Maria Luisa Célia Escalona de Dios

surgiram num momento de pleno emprego e aumento de renda, incremento de pessoas morando sozinhas, da ampliação das famílias nucleares e da intensificação da presença das mulheres no mercado de trabalho. Concomitante a essas mudanças, ocorreu uma ampla precarização do trabalho em diversos niveis salariais. Alguns destes profissionais descobriram possuir talentos, habilidades e conhecimentos que podiam ser transformados em mercadorias. Então, eles se reinventaram e passaram a ofertar estas expertises no formato de consultorias/serviços pessoais.

A atividade das consultorias pessoais abrange todas as áreas da vida cotidiana. Assim, para cada contratempo é factível encontrar alguém propondo uma solução específica e sob medida, existindo inúmeras ofertas destes profissionais em sites, vídeos, blogs e redes sociais, além de eles também serem protagonistas em programas de TV. Pode-se perceber que os serviços oferecidos por estes consultores têm um caráter pessoal e sob medida; exigem a interação face a face; exigem um esforço por parte de quem adquire o serviço, orientado para seu benefício e bem-estar; além de aprimoramento de capacidades, como economizar tempo, melhorar o desempenho no trabalho, melhorar a imagem e o estilo, organizar tarefas e a vida cotidiana, manter elevada a autoestima, entre outros.

Existem personals para quase tudo: para ensinar a se vestir com elegância e cuidar da imagem pessoal; para ajudar a fazer atividades fisicas e manter-se saudável; para auxiliar na elaboração do cardápio diário e ajudar a personalizar a dieta. Além disso, há personals que auxiliam nas compras, no preparo de jantares especiais e requintados. Há outros que levam cachorros para passear, outros, ainda, que ensinam a paquerar, a ser sensual e "apimentar a relação", e os que auxiliam nos preparativos para a chegada do "pimpolho", ajudam no planejamento da aposentadoria, na escolha da carreira, na administração das finanças, na organização do guarda-roupa à geladeira, escritórios e, até os arquivos no computador. Assim, percebi que, hoje em dia, está se tornado corriqueiro as pessoas terceirizarem atividades cotidianas e pessoais. 
Mercado de serviços pessoais: uma análise antropológica das técnicas gerenciais e sua relação com a intimidade | Maria Luisa Célia Escalona de Dios

As demandas por esses serviços, inexistentes até anos recentes, eram satisfeitas de outras formas, seja pelo próprio indivíduo, na medida em que possuía os conhecimentos e habilidades necessários, adquiridos por meio da socialização familiar; seja por outro membro da família, por amigos ou empregados que detinham essas habilidades. Esses serviços eram prestados no âmbito de relações mais amplas e permanentes, envolvendo a lógica da dádiva ou de assalariamento.

Usar o nome da atividade em inglês é uma estratégia que confere status à profissão e a seus profissionais; e pode dar a entender que sua clientela é de nível social e cultural elevado e alto poder aquisitivo. O termo personal pode ser interpretado como uma marca no campo dos serviços, ou seja, a expressão se transformou em um elemento que tem valor, que é distintivo. Desta forma, colocando quem o utiliza num status mais elevado, no setor de serviços, como sendo uma forma de valorização da sua atuação (BOURDIEU, 2000, 2003).

Os serviços prestados pelos personals envolvem proximidade de quem os presta com quem os recebe. Assim, o serviço é personalizado, mas a relação não, na medida em que ela é comercial. A constituição desse mercado é uma construção social que exige esforços, investimento de conhecimento, de criação de padrões, construção e manutenção de redes, ou seja, um grande trabalho relacional (ZELIZER, 2009). Portanto, dando a entender que a negociação entre personal e clientes ou futuros clientes exige esforço, é meticulosa e gradual, tendo em vista que os participantes da relação têm que se assegurar que as combinações são viáveis e as transações, veículos de troca e os limites estão adequados ao tipo de relação. As tecnologias gerenciais estão presentes na forma de atuação dos personals de formas variadas com o objetivo de controlar, racionalizar e de medir o desempenho dos efeitos dos seus serviços na vida dos clientes. 
Mercado de serviços pessoais: uma análise antropológica das técnicas gerenciais e sua relação com a intimidade | Maria Luisa Célia Escalona de Dios

\section{Alexandre, personal xamã e seus rituais perpassados por tecnologias gerenciais}

Antes de abordar a questão segue a apresentação de Alexandre, personal xamã, pois ela é pertinente para este relato. Alexandre é psicólogo e trabalhou na profissão durante os cinco anos que se seguiram à sua formatura e, foi nessa época que ele começou a ler os livros de Carlos Castañeda ${ }^{5}$ e de Helena Blavatski ${ }^{6}$, os quais influenciaram na sua formação. Entre 1989 e 1990 viajou para a Bélgica onde fez um curso de formação interdisciplinar holística, na Université de Paix ${ }^{7}$, entrando em contato com técnicas meditativas, rituais e de cura de religiões orientais e psicoterapias ditas alternativas. Continuando a sua formação mística e esotérica, em 1992 ele viajou para os EUA onde fez a sua formação em xamanismo. Em 1995, voltou ao Brasil e se instalou em Porto Alegre, onde começou ministrando palestras, workshops e cursos sobre rituais xamânicos para o autoconhecimento, além do uso de outras técnicas esotéricas e, ainda, atendimentos individuais. Ele escolheu Porto Alegre porque na época havia uma comunidade esotérica e mística que começava a florescer e, somando-se a isso, ocorreu a instalação de uma filial da Universidade da Paz, cuja sede no Brasil, fica em Brasilia. A sua família mora no estado de São Paulo e é proprietária de uma média indústria no setor metal mecânico. A clientela de Alexandre é composta por empresários e políticos.

Conforme Alexandre, ser xamã é ser um guia espiritual que utiliza práticas xamânicas para neutralizar as diversas dificuldades da vida, doenças emocionais e físicas, propiciando a autocura da pessoa que é acometida por esses males. Essas práticas consistem em utilizar os recursos

\footnotetext{
5 Carlos Castañeda escritor e antropólogo formado na Universidade da Califórnia foi considerado um dos gurus do movimento hippie (anos 1960 e 1970). Ele ficou famoso ao publicar, em 1973, um livro baseado na sua dissertação de mestrado"The teachings of Dom Juan", que no Brasil foi traduzido como "A erva do Diabo". Ao todo o autor publicou 11 livros autobiográficos relatando as suas experiências com o uso da erva peyote e com bruxo Dom Juan Matus da tribo Yaquis, deserto de Sonoro, Novo México. Fonte:www.vejaonline.com.br

${ }^{6}$ Helena Blavatsky (1831-1891) foi a idealizadora da Teosofia e a fundadora da Sociedade Teosófica. A Teosofia é um conjunto de doutrinas de caráter sincrético, místico, iniciático permeadas por reflexões filosóficas. Os seguidores da teosofia buscam através dos preceitos da teoria teosófica se autoconhecer e assim alcançar a elevação espiritual. Fonte: www.sociedadeteosofica.org

7 A Université de la paix é uma organização sem fins lucrativos, fundada em 1960 por Dominique Pire (prêmio Nobel da Paz de 1958) e por Raymond Vanderest livre pensador, com sede na Bélgica. Os seus objetivos são criar, disseminar e manter a paz no mundo, pelo diálogo pela empatia e o entendimento das diferenças. Fonte: www.universitedelapaix.org
} 
Mercado de serviços pessoais: uma análise antropológica das técnicas gerenciais e sua relação com a intimidade | Maria Luisa Célia Escalona de Dios

da natureza (flora, fauna e minerais) que aliados aos poderes mágicos de Alexandre (curativo, divinatório e comunicação com diversos espíritos), os potencializam, resultando em beneficios para seus clientes. Tendo em vista a incorporação cada vez mais intensiva, em suas abordagens terapêuticas, do tom "espiritual esotérico e xamânico" (conforme palavras de Alexandre), alguns dos seus clientes começaram a the solicitar que realizasse seus serviços nas suas empresas e nas suas casas.

Alexandre realiza os seguintes serviços: rituais e bênçãos dos mais variados em empresas, residências, veículos, espaços físicos de comitês eleitorais, gabinetes de políticos, escritórios, em eventos de lançamento de campanhas políticas, inauguração de empresas, lançamento de novos produtos, entre outros. Atualmente quase todo o seu tempo é ocupado fazendo atendimentos particulares para empresários e políticos e algumas vezes ao ano (duas a três) ele faz worshops de finais de semana.

Alexandre percebe a sua transição de psicólogo para personal xamã como inerente ao seu processo de aperfeiçoamento espiritual. Conforme seu relato, "segui o curso natural das coisas da vida, meu caminho já estava escrito, eu apenas aceitei o chamado da energia do meu espírito guia. O segredo é entrar e se manter no fluxo divino, sem duvidar, se entregar." A sua clientela é composta por politicos, empresários e executivos de alto escalão (gerentes seniores e diretores de empresas), o que averiguei por meio das entrevistas com Alexandre, de conversas com a sua secretária e olhando a sua agenda no computador.

De modo geral, percebeu-se que ele exerce o seu oficio junto aos clientes através de práticas, tais como - e conforme ele as denomina -: "viagens xamânicas de diversos tipos (busca por estados alterados de consciência)". Somam-se a isso a utilização de plantas, pedras, dos espíritos animais e seres da natureza, danças sagradas, exercícios respiratórios, dietas e chás especiais. Vale-se, também, da utilização de instrumentos como tambor, chocalho, sinos, bastões de madeira e outros elementos como incenso, velas, fogo, terra e água, além de melodias que são conhecidas 
Mercado de serviços pessoais: uma análise antropológica das técnicas gerenciais e sua relação com a intimidade | Maria Luisa Célia Escalona de Dios

como gênero New Age. Na sequência é descrito um ritual realizado por Alexandre com cinco de seus clientes.

O ritual tinha por objetivo transformar sonhos em realidade ou concretizar sonhos. Ao longo do ritual foram utilizados recursos como jogos de luz, incensos, fundos com músicas estilo New Age, toques de tambor, elementos que tinham a função de conferir dramaticidade, tornando a situação única e potencializando a sua eficácia simbólica. A primeira atividade do ritual foi a elaboração de um cartaz com recortes de revistas. As instruções recebidas foram: dividir a cartolina de forma radial em nove partes, cada uma delas representando uma dimensão da vida: amor, sucesso, prosperidade, viagens/amigos, carreira, espiritualidade, criatividade, saúde e família. No centro dessa forma radial, cada participante colou a sua própria foto. Em cada uma dessas áreas, os participantes tinham que expressar seus sonhos, por meio da colagem de recortes de revistas. Uma vez feito o cartaz, ele era colado na parede e os participantes, fitando o cartaz, eram solicitados a detalhar o sonho de cada uma das dimensões em forma de objetivos.

Conforme fala de Alexandre, que conduzia o ritual, "[...] Sonhos e realidade estão em dimensões paralelas, então não se encontram [...]. Para fazer a passagem da dimensão onírica para a real devemos utilizar as "Cinco Leis da Realidade". Assim, os sonhos deveriam ser detalhados por escrito em uma folha de papel em branco, seguindo as "Cinco Leis da Realidade", descritas por Alexandre, a saber: 1) a realidade somente aceita objetivos específicos ou exatos; 2) a realidade somente aceita objetivos que podem ser mensurados; 3) o objetivo deve ser possivel de ser alcançado; 4) o objetivo deve ser compativel com a situação atual de cada um, 5) o objetivo a ser alcançado deve ter data de início e fim. Quando algum dos participantes tinha dúvidas, Alexandre as esclarecia dando o seu próprio exemplo de como utilizou as cinco leis da realidade e alcançou seus objetivos. Uma vez terminada essa etapa, seguem-se exercícios de respiração, toques de tambor, danças e cantos como preparação para a próxima etapa. 
Mercado de serviços pessoais: uma análise antropológica das técnicas gerenciais e sua relação com a intimidade | Maria Luisa Célia Escalona de Dios

Alexandre tomou a palavra enunciando a próxima etapa: "realizar o mapeamento do eu em relação ao mundo terreno". Ele explica que, nessa fase, os participantes devem refletir e descrever quais são as suas fortalezas (pontos fortes) e fraquezas (pontos fracos). Do mesmo modo, "com quem" e com "o que" pode-se contar, na denominação de Alexandre os "apoiadores". E também “com quem" e com "o que” não se pode dispor, ou como ele os chama, os "opositores". Alexandre alerta que os "apoiadores" representam "oportunidades" e os "opositores" representam as "ameaças" e ambos são externos, ou seja, habitam o ambiente em que as pessoas vivem, fazendo parte do contexto de vida dos participantes. Ele conclui dizendo: "por serem eventos, pessoas ou coisas da realidade terrena, na maior parte das vezes, não podem ser alterados somente observados com sabedoria e reflexão". À medida que os participantes iam fazendo o exercício, eram encorajados por Alexandre a buscar inspiração em cartas de diversos tipos de baralhos espalhadas em círculos concêntricos pelo chão que, conforme Alexandre, tinham a função de inspirar a "superar as fraquezas, manter e reforçar as fortalezas, para ter sabedoria ao lidar com as ameaças e se abrir para as oportunidades e usufruir delas com prudência”. Ao final dessa etapa, os participantes guardavam as folhas de papel em que escreveram seus sonhos, conforme cinco leis da realidade, debaixo de cristais de quartzo transparente.

$\mathrm{Na}$ próxima e última etapa, os participantes, de olhos vendados, tinham que chegar do outro lado da sala enfrentando obstáculos de almofadas de diversos tamanhos, texturas e consistências e às vezes sendo impedidos pelos ajudantes de Alexandre. As almofadas e o impedimento dos ajudantes representavam as vicissitudes e as contingências da vida. A música de fundo utilizada era The conquest of Paradise ${ }^{8}$. Quando o participante chegava no final da sala era recebido por um dos ajudantes de Alexandre que lhe retirava a venda dos olhos, o congratulava pelo êxito na passagem e lhe dava uma pequena pedra de quartzo, como se fosse um prêmio, por ter conseguido vencer os obstáculos da travessia.

8 Tema principal da trilha sonora composta por Vangelis do filme "1492: A conquista do Paraíso" (1492:The Conquest of Paradise, 1492:Christophe Colomb). 
Mercado de serviços pessoais: uma análise antropológica das técnicas gerenciais e sua relação com a intimidade | Maria Luisa Célia Escalona de Dios

\section{Dora, personal organizer e suas técnicas de Gestão da Qualidade ritualizadas}

Dora presta um serviço personalizado em organização de ambientes, desde meados da década de 2000. A mãe é Arquiteta e o pai é Engenheiro Civil ambos são proprietários de uma construtora onde, também, trabalham os seus dois irmãos. Ela é alta, magra e se veste com tons neutros, cortes retos, mas sempre porta uma peça colorida. É uma pessoa de convivência fácil, conversa fluida, sorriso largo, figura forte e apesar de não se encaixar nos padrões vigentes de beleza, tem seu charme.

Dora é formada em Arquitetura de Interiores e iniciou a sua carreira profissional nos anos 1980, trabalhando em um órgão público como responsável pela área de Qualidade Total, na qual é especialista. No início da década de 1990 ela saiu do serviço público através de um Plano de demissão voluntária (PDV) e associou-se com uma amiga e colega dos tempos de graduação, constituindo um escritório de arquitetura.

Ao longo de sua vida profissional e, principalmente, quando atuou na esfera pública, teceu uma vasta rede de contatos que é um dos seus maiores capitais o outro é descender de uma família que tem tradição na área da construção civil. A sua transformação de arquiteta em personal organizer se deu aos poucos. Quando tinha o seu escritório de arquitetura, no início, ela elaborava mais projetos para famílias e depois de um tempo a maioria dos projetos eram destinados para pessoas sozinhas.

Esses clientes lhe solicitavam que, além do projeto de decoração, ela entregasse a residência pronta para morar, ou seja, ela teria que determinar como seria a organização dos objetos em cada ambiente, nos armários, no closet, na dispensa, na cozinha, e nos demais cômodos. Às vezes lhe era solicitado que treinasse a empregada doméstica. Nessa época, ela já deixava um esquema na porta de cada armário da casa, de como os objetos deveriam ser, ali, organizados. E foi dessa maneira que Dora vislumbrou uma nova maneira de atuar na sua profissão agregando os serviços de organização aos de decoração. 
Mercado de serviços pessoais: uma análise antropológica das técnicas gerenciais e sua relação com a intimidade | Maria Luisa Célia Escalona de Dios

Em meados dos anos 2000 ela decide separar-se da sócia e iniciar a carreira de personal organizer. Para isso ela foi aos Estados Unidos (EUA) fazer uma especialização em organização de ambientes. Durante esse período ela também fez dois seminários: um de transformação pessoal e outro para a prosperidade e riqueza com o guru/coach e disseminador da Programação Neurolinguistica Anthony Robbins ${ }^{9}$.

Os serviços de Dora compreendem: a organização de ambientes, de residências, de coleções, de mudanças residenciais e de escritórios e organização pós-luto e da manutenção dos ambientes organizados. Os serviços são cobrados por hora e restritos à organização de um ambiente, por exemplo: closet, guarda-roupa, quarto, cozinha, escritório, etc. que levam de quatro a seis horas para serem feitos. Os serviços que envolvem dois ou três ambientes são cobrados por diária (8h), ou seja, serviços que são realizados entre três a cinco dias. Quando os serviços são de grande escala organização de residências, mudanças, organização pós-luto e coleções dependo do seu volume e tamanho, Dora elabora um projeto.

O relato apresentado a seguir é a organização de um closet feminino. Ele foi escolhido por ser emblemático em relação aos aspectos que se expõem neste artigo. Na primeira visita na casa da cliente, após a contratação do serviço, Dora, personal organizer, explica detalhadamente em que consiste seu trabalho, como ele é feito e, além disso, também enfatiza que essa visita serve para fazer um levantamento de dados sobre o ambiente a ser organizado - o closet - e para conhecer as expectativas de Viviane ${ }^{10}$ (a cliente) em relação ao seu serviço. Durante a visita, Dora citava frases como: "a bagunça afeta os relacionamentos, ou desapegar, organizar e simplificar deixam a vida melhor, ou ainda organização é saúde".

Segunda visita: O trabalho de organização iniciou cedo, às nove horas da manhã. Dora e suas duas ajudantes, devidamente uniformizadas, chegaram ao prédio da cliente. Dora dá início a sua consultoria explicando para Viviane que as palavras: arrumar e organizar são coisas diferentes:

\footnotetext{
${ }^{9}$ www.tonyrobbins.com

$10 \mathrm{O}$ nome da cliente foi alterado para preservar a sua identidade.
} 
Mercado de serviços pessoais: uma análise antropológica das técnicas gerenciais e sua relação com a intimidade | Maria Luisa Célia Escalona de Dios

Arrumar é colocar as coisas em qualquer lugar e de qualquer jeito, já
organizar é ordenar os objetos de forma inteligente, para que sejam fáceis de
achar e ocupando os espaços certos, colocando as coisas de forma regular e
com certos critérios de classificação, de forma que, quando você precise uma
roupa, sapato ou acessório, não precise tirar os outros da frente para
alcançar o objeto que você deseja. Organizar é solucionar é resolver
problemas, é livrar-se de coisas que entulham a nossa vida.

E exemplifica mostrando os colares de Viviane, que estão pendurados numa das paredes do closet, dizendo

Esses colares estão arrumados, mas não estão organizados. Se estivessem
organizados, estariam separados por tamanho, tipo, cor, ou seja, por
critérios que depois vamos estipular. Deixa isso comigo.

Assim, Dora, tem por premissa que organizar é classificar os objetos segundo características estipuladas por ela. A diferença entre uma personal organizer, uma doméstica e uma faxineira, apesar de todas arrumarem armários e os ambientes da casa é que Dora estabelece categorias, códigos de organização e impõe a sua visão de mundo (BOURDIEU, 2002, 2004) e faz com que o cliente os incorpore por intermédio de treinamento.

Após, Dora inicia com a classificação das roupas, calçados, bolsas e acessórios em pilhas em cima da cama e no chão do quarto, que são cobertos cuidadosamente com uma lona de plástico preta. Quando essa etapa acaba, o closet fica vazio e as ajudantes de Dora se dedicam a sua limpeza. Os objetos são separados conforme o destino e cada destino tem recipientes de plástico de cores diferentes:

- Recipiente Conservar (cor rosa): nele são depositados todos os objetos que serão conservados. Ela escolheu a cor rosa porque significa afeto e para ela: "as pessoas somente conservam aquilo que é afetivo".

- Recipiente Lixo (cor preta): como o nome diz tudo que é acondicionado nele vai ser jogado fora, especificamente, no lixo. Segundo ela: "escolhi essa cor porque geralmente os latões de lixo são pretos"

- Recipiente Bazar (cor amarela): são objetos que serão vendidos em bazares ou brechós. Algumas vezes a própria Dora, ou conhecidas dela que atuam no ramo planejam e realizam os bazares para vendê-los. Para Dora a cor amarela é a cor do dinheiro e vender em um bazar ou para um brechó vai trazer dinheiro. 
Mercado de serviços pessoais: uma análise antropológica das técnicas gerenciais e sua relação com a intimidade | Maria Luisa Célia Escalona de Dios

- Recipiente Doação (cor laranja): são os objetos que serão doados para instituições ou para bazares de caridade. Segundo Dora: "escolhi essa cor por que é a cor da energia, o sol é mais laranja que amarelo, e temos que doar os objetos com energia boa, com desprendimento".

- Recipiente Conserto (cor azul): podem ser roupas, assessórios, utensílios e móveis que serão consertados. De acordo com a sua percepção:

o azul é uma cor que tem um significado próximo ao rosa que é das coisas a serem conservadas, pois tudo o que vai ser consertado é para ser conservado. O azul é uma cor de confiança e a gente somente aposta em consertar no que a gente confia e aposta que vai durar, que tem qualidade, que merece ser consertado.

- Recipiente Futuro (cor branca): neste recipiente são colocados roupas, pequenos objetos de decoração e assessórios que a cliente ainda tem algum apego e não quer se desfazer no momento. Num prazo de um ano ela terá que decidir o que vai fazer com estes objetos, se vai voltar a usá-los, se vai doá-los ou colocá-los a venda em um bazar. Dora acompanha atentamente esse processo estando ao lado da cliente no período de manutenção, que dura um ano. Nesse período Dora vai uma vez por mês na casa do (a) cliente verificar a adaptação dele(a) a nova maneira de organização e readequar o que não esteja dentro dos parâmetros estipulados por ela. Para Dora: "o futuro é uma tela em branco e a cliente ainda não sabe o que vai fazer com eles e também esse recipiente representa uma espécie de limbo".

- Recipiente Recordação (cor vermelha): Nele são colocados objetos em relação aos quais a proprietária tem um apreço especial e dos quais não quer se desfazer de modo algum. Esses objetos têm que ser realmente especiais e trazer recordações agradáveis. Segundo Dora: "vermelho representa a paixão, são coisas que a cliente tem uma paixão, lembram momentos especiais da vida dela, são importantes para ela". Essa etapa é acompanhada por frases do tipo: "Viviane simplifique a sua vida, jogue fora coisas que você não usa e não sabe onde estão, ou o acúmulo traz energias ruins, estagnadas. O descarte e a organização fazem fluir a energia”.

Viviane mostrava-se reticente em relação ao descarte, então Dora a leva para outro cômodo, acende um incenso e por meio do seu I-phone coloca 
Mercado de serviços pessoais: uma análise antropológica das técnicas gerenciais e sua relação com a intimidade | Maria Luisa Célia Escalona de Dios

uma música New Age, pedindo que a cliente comece a respirar lentamente. Depois, Dora lhe pede que desenhe, em uma folha de papel em branco, quais são os sentimentos que aquela "entulhação" no seu closet lhe provoca. Neste instante, Viviane desata a chorar copiosamente e é consolada afetivamente por Dora, que lhe pede para respirar pausadamente outra vez. Ao inspirar Viviane deveria mentalizar que estava respirando ordem, organização e ao expirar ela deveria imaginar-se exalando desorganização. Alguns minutos se passaram e, uma vez terminado o desenho, Dora fala "você não precisa mais disso na sua vida, isso é passado", e faz Viviane rasgar o desenho em vários pedaços que são queimados em um recipiente de cerâmica e depois as cinzas são enterradas no vaso de uma planta (Palmeira Raphis) que estava na sacada de Viviane.

Isto posto, ainda na sacada, e Dora lhe pergunta como ela se percebe no futuro, sem aquela "entulhação", e, novamente, pede a Viviane que faça um desenho, só que desta vez o tema é como ela se enxerga no futuro depois da organização do seu closet. Dora conclui essa etapa com as falas: "tenha domínio do seu tempo, descarte e organize-se". Concluído o desenho, ambas falam sobre o futuro desejado e Dora faz uma espécie de exercício de visualização do futuro com Viviane. No exercício Viviane foi orientada por Dora a visualizar a sua situação atual, no caso a desordem, como se fosse uma cena e, num quadrado menor, dentro do quadrado da desordem, a situação futura, ou seja, a ordem. Durante o exercício, o tamanho dos quadros vai se invertendo até que toda a cena seja tomada pelo quadro ou cena da ordem. Então Viviane é orientada e gritar shuosch para que a minúscula cena da desordem desapareça por completo e somente impere a cena da ordem. Conforme Dora esse procedimento é uma técnica de Programação Neurolinguística (PNL) que ela aprendeu nos seminários com Anthony Robbins. Em seguida, ambas vão para o quarto e iniciou-se a classificação dos objetos.

Quando Viviane ficava reticente em descartar algo Dora argumentava, por exemplo, “abra espaço na sua vida, desapegue, desapegue e descarte! Só assim seu closet ficará livre para que adquira mais roupas, 
Mercado de serviços pessoais: uma análise antropológica das técnicas gerenciais e sua relação com a intimidade | Maria Luisa Célia Escalona de Dios

mais sapatos, mais de tudo!". E acrescentava exemplos de sua vida evidenciando como o seu método de organizar a tornaram numa pessoa bem-sucedida em todos os sentidos e uma profissional de prestígio. As ajudantes recolocam os objetos no closet conforme as orientações de Dora.

Nesse interim, Dora pede para que a cliente elabore um plano denominado $O$ meu futuro organizado, em que Viviane deve expor as ações que ela fará para manter a organização do closet. Na sequência, Dora explica que cada ação deve ser específica concreta, ter data de início e fim, deve ser elaborada dentro das possibilidades de Viviane. A partir do momento em que esta fase inicia Viviane é aconselhada a não mais entrar no closet. No dia seguinte, que é o último dia do trabalho de organização, Viviane e Dora se reúnem a fim de comentar o plano que Viviane elaborou, para que Dora possa fazer os ajustes nas ações elaboradas pela cliente.

O final da organização é o momento apoteótico: a porta do closet está fechada com uma fita de inauguração cor de rosa e Dora pede que Viviane desmanche o laço. E ocorre a revelação, ou seja, um closet perfeitamente organizado, recendendo a lavanda, com roupas milimetricamente dispostas. Dora exclama em tom solene e levemente entusiasmado: "enfim, cada coisa em seu lugar e um lugar para cada coisa".

\section{Tecendo paralelismos e encontrando discrepâncias}

Os processos relatados mostram metodologias que borram as fronteiras entre as dimensões mágica e empresarial. Em ambos, os interlocutores Alexandre, personal xamã; e Dora, personal organizer, se valem de tecnologias gerenciais, valores empresariais e rituais para conduzir o processo de consultoria. Eles buscam, por meio da ideologia de gestão (GAULEJAC, 2007; BOUSSARD, 2008), pautada por regras racionais e prescrições exatas, traduzir sonhos, sentimentos, emoções e dirimir dificuldades, ou seja, converter atividades humanas em números, especificamente, em indicadores de desempenho e, portanto, mensuráveis. Dito de outra forma, a utilização de conjuntos de técnicas gerenciais, ou, como denominado por Gaulejac (2007) o poder gerencialista, provoca um 
Mercado de serviços pessoais: uma análise antropológica das técnicas gerenciais e sua relação com a intimidade | Maria Luisa Célia Escalona de Dios

engajamento subjetivo das pessoas. Nos dois casos relatados, o cliente não é passivo, ele tem que se esforçar para conquistar um estado ideal de existência realizando seus sonhos, adotando uma vida organizada e adquirindo, através da autodisciplina, o equilíbrio emocional. Logo, seguir as regras determinadas pelos personals xamã e organizer deixam o cliente numa espécie de devir, se ele ainda não chegou lá é por que ainda não pratica as prescrições de forma eficiente (GAULEJAC, 2007).

$\mathrm{O}$ ritual funciona como uma mola propulsora para que os clientes tenham a oportunidade de concretizar seus projetos de vida (PEIRANO, 2002 e 2003). Outro ponto significativo é que tanto Alexandre quanto Dora evidenciaram o sucesso de suas abordagens, através dos seus próprios exemplos de vida bem-sucedida e, sendo coerentes com as suas crenças em seus métodos, eles os praticam, o que aumenta e reforça a eficácia simbólica (LÉVI-STRAUSS, 2003) das práticas adotadas. Para Lévi-Strauss (2003), a eficácia do pensamento mágico é garantida pela homologia entre o corpo e o psiquismo. Assim, as técnicas gerenciais ritualizadas, ou os rituais permeados por técnicas gerenciais, agem como o pensamento mágico, ou seja, integram elementos desorganizados num sistema organizado e compartilhado. Em outras palavras, o que antes era tido como acaso da vida e experimentado de forma incoerente e desarticulada é dotado de sentido, através da combinação de técnicas gerencias e rituais, feita pelos personals xamã e organizer.

Analisando o método de Alexandre, personal xamãa, percebe-se na sua técnica das "Cinco Leis da Realidade" uma tecnologia gerencial desenvolvida nos anos 1950 por Peter Drucker11 (2010) que se denomina Método SMART. O anagrama SMART é composto pelas iniciais das palavras em inglês: Specific (específico), Mesurable (mensurável), Attainable (atingivel), Realist (realista) e Timely (temporal). Em breves palavras, a referida tecnologia tem o intuito de alinhar, entre os administradores/empresários e funcionários, quais resultados desejam ser alcançados pela empresa e quais serão as formas de mensurá-los. Para tanto, o administrador/empresário deve

\footnotetext{
${ }^{11}$ Considerado um dos gurus da Administração de Empresas do século XX.
} 
Mercado de serviços pessoais: uma análise antropológica das técnicas gerenciais e sua relação com a intimidade | Maria Luisa Célia Escalona de Dios

analisar como a empresa se encontra no presente e como ele a deseja no futuro, isto é, a longo prazo, ou seja, dali a dez a trinta anos (DRUCKER, 2010). O Método SMART de formular objetivos também é utilizado no Workshop EMPRETEC ${ }^{12}$ com o intuito de que o participante aprenda a elaborar metas ou objetivos específicos, concretos, que possam ser medidos, que tenham data de início e término e que se enquadrem na realidade de quem os elabora. Ambos, Dora e Alexandre, participaram do workshop EMPRETEC que disseminava essa técnica. Em suma, o Método SMART, estava disfarçado pela retórica das "Cinco Leis da Realidade", na atuação do personal xamã Alexandre. Por seu turno a consultora em organização Dora também recorre a esta tecnologia gerencial para instruir a cliente como escrever as ações para manter a organização no plano "Meu Futuro Organizado".

Por sua vez, na etapa do ritual/vivência em que Alexandre se refere ao "mapeamento do eu em relação ao mundo terreno" houve mais uma vez a inserção de outra tecnologia gerencial, desta feita a Matriz FOFA ou PFOA. Assim sendo, as iniciais do nome Matriz FOFA ou PFOA ${ }^{13}$ significam, respectivamente, FOFA: Fortalezas, Oportunidades, Fraquezas e Ameaças; ou PFOA: Pontos Fortes e Fracos, Oportunidades e Ameaças. A mencionada tecnologia gerencial, de acordo com a teoria da Administração, é um instrumento importante para a elaboração do Planejamento Estratégico de uma empresa. Resumindo, o método consiste em recolher dados internos da empresa (setores) - ambiente interno - que são classificados em pontos fortes e fracos e que podem ser controlados, e dados externos a empresa ambiente externo -, que são categorizados como ameaças e oportunidades e que não podem ser controladas apenas acompanhadas no seu decurso. E através do cruzamento das informações obtidas dessa análise a empresa é

\footnotetext{
12 O Empretec é uma metodologia da Organização das Nações Unidas - ONU - voltada para o desenvolvimento de características de comportamento empreendedor e para a identificação de novas oportunidades de negócios, promovido em 34 países. Aqui no Brasil ela é difundida através do SEBRAE (www.sebrae.com.br/empretec).

13 Matriz SOWT é o nome utilizado em inglês (Strenghts ou Pontos Fortes/Fortalezas; Opprtunities ou Oportunidades; Threats ou Ameaças e Weaknesses ou Fraquezas/Pontos Fracos.
} 
Mercado de serviços pessoais: uma análise antropológica das técnicas gerenciais e sua relação com a intimidade | Maria Luisa Célia Escalona de Dios

posicionada estrategicamente ${ }^{14}$ (CERTO e PETER, 2005 e IRELAND et al., 2014).

Ao observar detalhadamente a forma pela qual Dora conduz a sua consultoria pessoal em organização, constatou-se que ela utiliza de forma ritualizada, por intermédio de recipientes de plástico coloridos, alguns métodos consagrados na Gestão da Qualidade Total, o método japonês 5S. Este método é assim denominado devido à primeira letra de cinco palavras japonesas Seiri, Seiton, Seiso, Seiketsu e Shitsuke, é considerado a etapa inicial e base para implantação de Programas de Qualidade Total, nas empresas. Detalhando o significado que as cinco palavras japonesas adquiriam em português temos (FALCONI, 1992):

- Seiri: senso de seleção, descarte e senso de utilização. Fase em que se faz a seleção dos objetos, separando o que é considerado útil e o que será descartado. O destino dos objetos descartados é a doação ou venda como sucata.

- Seiton: senso de ordenação, logo, um lugar para cada coisa e cada coisa no seu lugar.

- Seiso: senso de limpeza, ao limpar, manter sempre o lugar limpo, evitando sujeiras.

- Seiketsu: sendo de higiene ou asseio, isto é, padronizar práticas saudáveis, evitando poluição visual e de sujeitas no ambiente de trabalho.

- Shitsuke: senso de autodisciplina, a saber, conscientizar-se e assumir responsabilidade de seguir os padrões saudáveis.

$\mathrm{O}$ método dos $5 \mathrm{~S}$ tem a finalidade de mobilizar, motivar e conscientizar todos os funcionários da empresa para a implementação do Programa de Qualidade Total. Nesse sentido, através da organização e da disciplina no local de trabalho, pretende mudar o comportamento dos

\footnotetext{
14 São quatro quadrantes estratégicos: Estratégia de Manutenção (predominância de pontos fortes e ameaças; Estratégia de Abandono (predominância de pontos fracos e ameaças); Estratégia de Desenvolvimento (predominância de oportunidades e pontos fortes) e Estratégia de Crescimento (predominância de pontos fracos e oportunidades).
} 
Mercado de serviços pessoais: uma análise antropológica das técnicas gerenciais e sua relação com a intimidade | Maria Luisa Célia Escalona de Dios

funcionários da empresa para que incorporem os princípios do método $5 \mathrm{~S} \mathrm{e}$ se autodisciplinem em relação não só à organização do ambiente de trabalho, mas também para a sua vida (FALCONI, 1992). Dora utiliza o método $5 \mathrm{~S}$ criando, por meio dele, maneiras originais para que a sua cliente se conscientize de que deve alterar seu estilo de vida atual para um estilo organizado, sem acúmulo de objetos e com descarte constante para poder consumir cada vez mais. Dora conhece esses métodos porque se especializou em Qualidade Total e foi Gerente de Qualidade. Deste modo, reconverte o capital (BOURDIEU, 2000 e 2005) adquirido nesse período, em capital econômico na sua atual atividade, visto que ela aplica, na sua consultoria, uma técnica consagrada do Programa de Qualidade Total de forma ritualizada.

Em relação à forma de atuação desses dois consultores pessoais, pode-se inferir que aparecem duas das três formas de objetivação ${ }^{15}$ dos sujeitos elencadas por Foucault $(2005 ;$ 2010), que são as práticas discursivas e as práticas subjetivantes. A primeira, por intermédio dos discursos e saberes destes personals que ajudam, intervém e controlam a vida dos seus clientes. A segunda, evidenciada pelas técnicas de si praticadas pelos sujeitos pesquisados através das indicações dos referidos personals que ditam, aconselham, elaboram práticas cotidianas para seus clientes, logo utilizam tecnologias de si (FOUCAULT, 2005). Como no caso de Dora, que faz a sua cliente elaborar um plano para ser organizada, e no de Alexandre, que ensina aos seus clientes métodos de realizarem seus sonhos. Por meio da ritualização das técnicas gerenciais os clientes de Dora e Alexandre identificam o que, como e quando devem modificar no "Eu" para produzir a subjetividade adequada. No caso dos clientes de Alexandre para obterem êxito nas áreas descritas no cartaz. Em relação à cliente de Dora para que ela tenha sucesso no seu plano de uma vida organizada.

\footnotetext{
15 Práticas discursivas, Práticas objetivantes cujo objeto é o sujeito normalizável (louco/ são; delinquente;/homem bom) e Práticas subjetivantes ou processos pelos quais os seres humanos transformam a si mesmo em sujeito, por meio de práticas por Foucault denominadas técnicas de si.
} 
Mercado de serviços pessoais: uma análise antropológica das técnicas gerenciais e sua relação com a intimidade | Maria Luisa Célia Escalona de Dios

\section{Eduardo, personal trainer e as tecnologias gerenciais junto aos seus clientes}

Eduardo atua como Personal Trainer há 24 anos e descende de uma família de médicos. Desde pequeno, ele pratica vários esportes como Tênis, Golfe, Vôlei, Natação e Vela. Em parte, sua trajetória profissional foi facilitada pelas profissões do pai e do tio materno um é traumatologista e o outro cardiologista. Logo depois de formado Eduardo especializou-se, nos EUA, nas áreas de educador físico para cardiopatas e traumatizados. Na volta ao Brasil em 1993, ele começou a trabalhar na clínica da família, da qual é sócio, atendendo os pacientes do tio, do pai e, mais tarde, do primo, que é geriatra. $\mathrm{Na}$ sala em que ele realizava os atendimentos, no início da sua carreira, encontram-se expostos na parede os certificados das suas qualificações, assim como nas salas de seu pai, tio e primo.

Com o passar do tempo, mais algumas especializações no exterior, e à medida que a sua clientela particular a domicílio foi aumentando, ele deixou de atender na clínica da família. No início da sua carreira, Eduardo, atendia pessoas com traumas sérios, idosos e cardiopatas que requeriam exercícios específicos para as suas moléstias. Posteriormente, quando começou a atender somente como personal trainer, a domicílio, passou a atender executivos que queriam manter a forma e não tinham tempo e paciência para frequentar academias, ou não queriam submeter-se às regras desses estabelecimentos. Hoje em dia, Eduardo atende homens e mulheres, quase que somente executivos e empresários.

Eduardo utiliza para cada cliente as seguintes planilhas por ele elaboradas: Planilha de Exercícios (treinos), Planilha de Avaliação e Planilha de Monitoramento do cliente. Na Planilha de Exercícios ele registra as sequências dos treinos, as datas e recuperações das aulas, os exercícios preferidos e detestados pelo cliente, lesões e dificuldades físicas. Na Planilha de Avaliação, além das avaliações realizadas (o período delas varia de cliente para cliente), constam as medidas corporais (peso, altura, teor de gordura, circunferência do tórax, da cintura e do abdômen, coxas, tornozelos, braços e pescoço) e suas variações ao longo do tempo em forma de gráfico. 
Mercado de serviços pessoais: uma análise antropológica das técnicas gerenciais e sua relação com a intimidade | Maria Luisa Célia Escalona de Dios

A Planilha de Monitoramento é a mais interessante delas porque reúne diversas informações sobre o cliente, desde as mais corriqueiras e que constam em qualquer cadastro, até comentários pessoais que o cliente fez sobre os resultados obtidos através dos exercícios e sobre momentos específicos da vida pessoal do cliente. As informações registradas são:

- Dados cadastrais do cliente (nome, idade, profissão, cargo, endereço, email, telefones e celulares);

- Nome do cônjuge, idade, profissão, nome dos filhos, idade e colégio ou universidade (curso), ou se são adultos profissão;

- Médicos que o cliente frequenta;

- Eventos marcantes no passado, no presente e no futuro, tanto da vida profissional como pessoal do cliente. Por exemplo: evento passado morte do pai há cinco anos; evento futuro, aposentadoria daqui a dois anos, casamento da filha no final do ano; evento presente: amigo do cliente diagnosticado com câncer, dificuldades no trabalho.

- Interesses Especiais tais como: animais de estimação, tipos de esporte, hobbies (esquiar, culinária, vinhos, cerveja), tipo de viagens, modalidades de lazer.

- Momentos UAU16! (extraordinários): Neste item são registrados comentários do cliente sobre os efeitos dos exercícios. Exemplo das anotações de Eduardo:

Anotação referente a uma cliente de 50 anos casada: A (nome da cliente) estava tomando sol na paria e um rapaz de trinta e poucos anos sarado, começou a paquerá-la e pediu seu telefone e ela desconversou. Ela gostou do ocorrido e se sentiu o máximo.

Anotação referente a um cliente de 68 anos: (Nome do cliente) estava sendo num café em Amsterdã com a sua esposa e quando ela foi ao banheiro, uma jovem, bonita, loira de olhos azuis que estava sentada na mesa da frente levantou-se e lhe entregou um papel com o seu celular e foi embora. Ele ficou muito lisonjeado.

Com essa planilha ele administra o seu relacionamento com os clientes. Essas informações são utilizadas durante as aulas para motivar os alunos, conhecer mais aprofundadamente seus interesses, seu momento de vida e ajustar cada vez mais o seu serviço aos clientes. Eduardo também faz

\footnotetext{
${ }^{16}$ Eduardo gosta muito dessa expressão, pois ele fez um workshop, nos EUA, com o guru da administração (atendimento ao cliente) Tom Peters, e a referida expressão é muito utilizada por Tom Peters que inclusive lançou um livro com esse nome “A busca do UAU” (1997).
} 
Mercado de serviços pessoais: uma análise antropológica das técnicas gerenciais e sua relação com a intimidade | Maria Luisa Célia Escalona de Dios

gráficos medidos no tempo (eixo $\mathrm{x}$ tempo, eixo y índice) para cada cliente sobre os dados dos exames clínicos dos alunos. Exemplo: Índice de colesterol, Índice de glicose etc.; e também das radiografias e das tomografias. Através destas tecnologias gerenciais ele captura e contabiliza os efeitos do seu trabalho tanto em termos de melhora da saúde quanto os efeitos sociais. Ao elaborar gráficos com indicadores da saúde dos clientes, ele está avaliando o desenvolvimento dos resultados do seu trabalho e materializando-os perante os clientes. As planilhas auxiliam Eduardo uniformizar, expor de forma condensada a situação dos alunos, a quantificar e comparar os resultados do seu trabalho junto aos clientes.

\section{Marta, Personal Stylist e a sua planilha de pontos fortes e fracos.}

Para entender como Marta transformou seu "bom gosto" para se vestir no serviço de Personal Stylist é preciso reconstituir, brevemente, o seu percurso de vida. Na infância, Marta aprendeu a costurar com sua mãe, que era considerada pela sociedade local uma mulher elegante. Na adolescência aprimorou seu aprendizado sobre estilo através das revistas de moda e de corte e costura. Em meados dos anos oitenta, na cidade do interior onde morava, Marta abriu uma butique de roupas femininas na qual comercializava marcas que, na época, estavam em voga como Zoomp, Fórum, M.Oficer, Ellus. A loja fez muito sucesso durante 12 anos. Para promover a loja ela realizava um desfile a cada início de estação. Durante os anos em que foi proprietária de loja, Marta tinha acesso a palestras, workshops e cursos sobre moda, estilo e tendências e, ainda, aos desfiles de lançamento das marcas que adquiria para sua loja nas cidades de São Paulo, Rio de Janeiro e Belo Horizonte, bem como catálogos com tendências de moda e de cores, instruções de como combinar as roupas de acordo com os estilos vigentes e o tipo físico. E assim, ao longo dos anos, ela foi adquirindo e construindo um conhecimento a respeito da moda, sobre estilo, cores, estampas e sobre a dinâmica das tendências. Poderiamos inferir que esta fase da vida foi equivalente, para ela, a um curso superior em moda e estilo. No final dos anos noventa a loja começou a dar prejuízo o que acarretou seu 
Mercado de serviços pessoais: uma análise antropológica das técnicas gerenciais e sua relação com a intimidade | Maria Luisa Célia Escalona de Dios

o fechamento e Marta mudou-se para Porto Alegre. Nessa época que ela começou a atuar como personal stylist em duas empresas de recolocação de executivos cujas proprietárias eram suas amigas de longa data e aos poucos foi construindo sua clientela composta por homens $(30 \%)$ e mulheres $(70 \%)$ dos meios empresarial, executivo (gerentes seniores e diretores de empresas) e políticos. A sua consultoria de estilo tem a duração de dois meses.

As técnicas gerenciais que Marta utiliza na sua consultoria de estilo são: um diagnóstico, uma planilha de pontos fortes e fracos do tipo físico da cliente e o tipo de roupa que mais se ajusta à cliente dependendo da silhueta. Conforme seu relato ela teve a ideia do diagnóstico e da planilha de pontos fortes e fracos durante o wokshop Empretec do qual participou no ano 2001. Ela transformou o diagnostico empresarial que analisava as áreas da empresa para a sua área de trabalho. Marta faz um levantamento de informações para elaborar um diagnóstico da cliente em relação a diversos aspectos. Averigua gostos, os projetos de vida e de carreira, as expectativas que a cliente deseja alcançar com a consultoria. Por sua vez, a planilha com os pontos fortes e fracos sobre o tipo físico da cliente ela adaptou da Matriz PFOA ou FOFA (CERTO e PETER, 2005).

Em relação ao diagnóstico, Marta inicia perguntando para a cliente quais são as suas expectativas em relação à consultoria de estilo. Na parte dos gostos, ela averigua as preferências sobre comidas, tipos de alimentos, artistas, programas de TV, filmes, tipos de lazer, estampas de tecido, cores, perfumes e marcas. Com referência aos aspectos dos projetos de vida e carreira Marta pergunta como elas se enxergam daqui a cinco anos, ou seja, ela utiliza a tecnologia gerencial de visão de futuro utilizada no planejamento estratégico empresarial (CERTO e PETER, 2005). No que concerne a planilha de pontos fortes e fracos sobre a silhueta da cliente, Marta classifica os tipos fisicos os avalia conforme os itens: magra, gorda, alta, baixa, tronco curto, tronco longo, pernas curtas, barriga saliente, busto grande, busto pequeno, ombros caídos, ombros largos, quadril avantajado, pouco bumbum, bumbum avantajado, sem cintura, cintura definida. É o conjunto desses itens que, segundo, Marta determina as peças de roupa que a cliente deve 
Mercado de serviços pessoais: uma análise antropológica das técnicas gerenciais e sua relação com a intimidade | Maria Luisa Célia Escalona de Dios

evitar e aquelas que ela deve utilizar, para obter a sensação de uma silhueta equilibrada, ou seja, que não chame a atenção para alguma parte específica do corpo. Exemplo de uma planilha elaborada por Marta para uma cliente:

Quadro 1 - Planilha Pontos Fortes e Fracos

\begin{tabular}{|c|c|c|c|}
\hline \multicolumn{4}{|c|}{ Planilha de pontos fortes e fracos } \\
\hline Nome da cliente & Idade & Altura & Peso \\
\hline 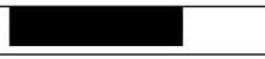 & 39 anos & $1 \mathrm{~m} 78 \mathrm{~cm}$ & $80 \mathrm{~kg}$ \\
\hline \multicolumn{2}{|l|}{ Pontos fortes } & \multicolumn{2}{|c|}{ Pontos fracos } \\
\hline \multicolumn{2}{|c|}{$\begin{array}{l}\text { Alta } \\
\text { Ombros largos } \\
\text { Pernas longas e torneadas } \\
\text { Rosto bonito } \\
\text { Olhos azuis e grandes }\end{array}$} & \multicolumn{2}{|c|}{$\begin{array}{l}\text { Volume na barriga, nos quadris e no busto. } \\
\text { Sem cintura }\end{array}$} \\
\hline \multicolumn{2}{|c|}{ Objetivos da mudança de estilo } & \multicolumn{2}{|c|}{$\begin{array}{l}\text { - Usar roupas que criem linhas que } \\
\text { alonguem a silhueta. } \\
\text { - Chamar a atenção para o rosto e } \\
\text { ombros. }\end{array}$} \\
\hline \multicolumn{2}{|c|}{ Peças de roupas permitidas } & \multicolumn{2}{|c|}{ Peças de roupas proibidas } \\
\hline \multirow{5}{*}{\multicolumn{2}{|c|}{$\begin{array}{l}\text { Optar por cores escuras } \\
\text { Listras diagonais e verticais } \\
\text { Roupa com recortes e pences } \\
\text { Saias e vestidos retos, cumprimento no } \\
\text { joelho ou abaixo. } \\
\text { Calças de corte reto com a bainha tocando } \\
\text { o peito do pé e cintura no lugar. } \\
\text { Decotes em V ou U }\end{array}$}} & \\
\hline & & \multicolumn{2}{|c|}{ Calça afunilada e } \\
\hline & & \multicolumn{2}{|c|}{ Calça com boca larga } \\
\hline & & \multicolumn{2}{|c|}{$\begin{array}{l}\text { Calça com pregas } \\
\text { Calça de cintura baixa }\end{array}$} \\
\hline & & \multicolumn{2}{|c|}{$\begin{array}{l}\text { Echarpes ao redor do pescoço, gola alta e } \\
\text { gargantilhas }\end{array}$} \\
\hline \multicolumn{2}{|c|}{$\begin{array}{l}\text { Blusas abaixo da barriga na altura do } \\
\text { quadril }\end{array}$} & \multicolumn{2}{|c|}{$\begin{array}{l}\text { Roupas claras e brilhantes } \\
\text { Jaqueta na cintura/curta } \\
\text { Roupas de tecidos volumosos } \\
\text { Saia rodada } \\
\text { Pregas, babados e drapeados } \\
\text { Blusa por dentro da calça } \\
\text { Cintos e faixas que marquem a cintura } \\
\text { Vestidos com recorte abaixo do busto } \\
\text { Roupas que mostrei a barriga }\end{array}$} \\
\hline
\end{tabular}

Fonte: Planilha de pontos fortes e fracos fornecida pela personal stylist 
Mercado de serviços pessoais: uma análise antropológica das técnicas gerenciais e sua relação com a intimidade | Maria Luisa Célia Escalona de Dios

Marta, Personal Stylist, por sua vez determina e ensina para as clientes o que é ser elegante, quais os estilos que elas devem seguir, que tipo de roupa fica melhor conforme o tipo físico, qual o conjunto de cores que mais as favorecem e quais as combinações de cores que são sofisticadas, elegantes, inovadoras, modernas, contemporâneas e clássicas. Ela detém o poder simbólico (BOURDIEU, 2004) de ditar categorias, de estabelecer noções de bom gosto, sofisticação, elegância e beleza, porque quem contrata seus serviços a reconhece como detentora desses capitais (BOURDIEU, 2005). Ela ensina para as clientes que existem quatro tipos de estilo, a saber: formal, informal, casual e esporte. Além disso, existem ocasiões específicas para usá-los e, ainda, cada um deles passa uma determinada imagem. Na sequência, para se ter uma ideia de o que a personal stylist entende e ensina para as clientes sobre estilo, demonstro a Planilha de estilos elaborada por Marta. Nela são mostrados os quatro tipos de estilo arbitrados por Marta, o formal, o informal, o casual e o esportivo. 
Mercado de serviços pessoais: uma análise antropológica das técnicas gerenciais e sua relação com a intimidade | Maria Luisa Célia Escalona de Dios

\section{Quadro 2 - Planilha de estilos}

Planilha de estilos

\begin{tabular}{|c|c|c|c|}
\hline Estilos & Ocasiões de uso & Características & $\begin{array}{l}\text { Tipos de roupas } \\
\end{array}$ \\
\hline Formal & $\begin{array}{l}\text { Coordenação de } \\
\text { reuniões formais, } \\
\text { Apresentações, } \\
\text { Visitas a clientes, } \\
\text { Negócios } \\
\text { Internacionais. }\end{array}$ & $\begin{array}{l}\text { Credibilidade } \\
\text { Confiança } \\
\text { Autoridade }\end{array}$ & $\begin{array}{l}\text { Tailleur ou Terninho coordenado } \\
\text { Vestido com blazer ou Spencer } \\
\text { Vestidos tubinhos ( clássicos) } \\
\text { Camisas e Blusas de tecidos nobres } \\
\text { Sapato scarpim ou Channel com salto alto } \\
\text { Bolsa de couro de marca consagrada } \\
\text { Joias ou bijuterias discretas } \\
\text { Meia-calça transparente }\end{array}$ \\
\hline Informal & $\begin{array}{l}\text { Coordenação de } \\
\text { reuniões formais, } \\
\text { Apresentações, } \\
\text { Visitas a clientes }\end{array}$ & $\begin{array}{l}\text { Descontração } \\
\text { Credibilidade } \\
\text { Confiança } \\
\text { Autoridade }\end{array}$ & $\begin{array}{l}\text { Blazers ou Terninhos desordenados } \\
\text { Jaqueta e alças sociais retas } \\
\text { Saias retas, evasês (sem pontas) } \\
\text { Vestidos tubinhos(clássicos) } \\
\text { Camisa de algodão } \\
\text { Blusas de algodão } \\
\text { Suéteres leves, gola alta, V, careca } \\
\text { Sapatos scarpim ou Channel com salto médio } \\
\text { Bolsa de couro de marca consagrada } \\
\text { Joias ou bijuterias discretas } \\
\text { Meia-calça transparente }\end{array}$ \\
\hline Casual & $\begin{array}{l}\text { Reuniões, } \\
\text { Projetos ou } \\
\text { Treinamentos, } \\
\text { Visitas a clientes. }\end{array}$ & $\begin{array}{l}\text { Descontração } \\
\text { Acessível } \\
\text { Flexível }\end{array}$ & $\begin{array}{l}\text { Cardigãs } \\
\text { Twin -set } \\
\text { Camisas de algodão } \\
\text { Camisetas de algodão } \\
\text { Tricôs } \\
\text { Suéteres leves, gola alta, V e careca } \\
\text { Jaquetas ou blazers } \\
\text { Vestidos mais descontraídos (sem exageros) } \\
\text { Calças um pouco mais descontraídas (sarja, } \\
\text { gabardine) } \\
\text { Saias de algodão, veludo (sem exageros) } \\
\text { Meias opacas (fio 40) } \\
\text { Botas, mocassins, plataformas, scarpim ou } \\
\text { Channel } \\
\text { Bijuterias rústicas com pedras } \\
\text { Bolsas mais descontraídas de marcas consagradas } \\
\text { Vestidos mais descontraídos (sem exageros) }\end{array}$ \\
\hline Esportivo & $\begin{array}{l}\text { Trabalhos, } \\
\text { projetos, sessões } \\
\text { de treinamento } \\
\text { que exijam } \\
\text { criatividade e } \\
\text { descontração. }\end{array}$ & $\begin{array}{l}\text { Agradável } \\
\text { Receptiva } \\
\text { Provisória }\end{array}$ & $\begin{array}{l}\text { Calça cargo( utilitária) } \\
\text { Calças e saias jeans de veludo, algodão ou náilon } \\
\text { Camisas de algodão } \\
\text { Camisetas de algodão } \\
\text { Camisetas temáticas } \\
\text { Tricôs } \\
\text { Jaquetas de jeans, veludo, nylon ou moletom } \\
\text { Tênis, Mocassins, botas de couro, camurça e } \\
\text { nobuk, solados de borracha. } \\
\text { Sandálias } \\
\text { Acessórios rústicos (osso, madeira, borracha) } \\
\text { Relógio esportivo } \\
\text { Bolsa de náilon, couro, ou nobuk }\end{array}$ \\
\hline
\end{tabular}

Fonte: Planilha de Estilos elaborada pela personal stylist, Marta, para as clientes.

Ao apresentar os estilos em uma planilha autoexplicativa, Marta condensa as informações de forma didática, fazendo com que as clientes se ajustem as normas do que ela entende por bem vestir e vestir-se com elegância. Ao utilizar a tecnologia gerencial planilha, Marta, apresenta os 
Mercado de serviços pessoais: uma análise antropológica das técnicas gerenciais e sua relação com a intimidade | Maria Luisa Célia Escalona de Dios

preceitos de estilo por ela elaborados numa linguagem semelhante aquela utilizada por seus clientes, tendo em vista que eles são executivos(as), empresários(as) e políticos(as), portanto na sua vida profissional se utilizam de tecnologias gerenciais.

Assim como Dora, personal organizer, Marta também cria categorias, códigos e impõe a sua visão (BOURDIEU, 2002) sobre estilo e elegância para as suas clientes Marta estipula normas de estilo de acordo com o tipo físico de cada cliente que ela aprendeu ao longo da sua trajetória como lojista. Desta forma, Marta normaliza cada cliente - dentro do que ela acredita ser um estilo adequado e elegante - no formato da planilha fixando objetivos de estilo, listando pontos fortes e fracos para cada cliente. Nas palavras de Marta "uma pessoa vestida adequadamente conforme seu tipo físico e a ocasião garante a sua empregabilidade, pois demonstra ser uma pessoa que tem consciência de adequação a cada situação". Assim, Marta adapta a cliente as necessidades da empresa evitando que ela tenha "falhas de empregabilidade" (GAULEJAC, 2007, p. 184). Ao elaborar uma planilha para cada cliente, Marta didaticamente vai transmitindo as informações de forma esquemática, ensina a cliente a gerenciar seu estilo, transformando-o em uma competência para se posicionar de maneira mais adequada no mercado de trabalho. 
Mercado de serviços pessoais: uma análise antropológica das técnicas gerenciais e sua relação com a intimidade | Maria Luisa Célia Escalona de Dios

\section{Considerações finais}

Ao mesclar elementos rituais e tecnologias gerenciais os personals Alexandre e Dora fazem uma bricolagem (LÉVI-STRAUSS, 1989). Logo Alexandre traz para o ritual elementos da realidade social dos seus clientes, as tecnologias gerenciais, tendo em vista que a maioria deles é do meio empresarial e político. Contudo ele os exibe reelaborados no formato das "Cinco Leis da Realidade" que é o equivalente do Método SMART e do "mapeamento do eu no mundo terreno" que equivale a Matriz PFOA ou FOFA. Por sua vez, Dora ritualiza técnicas da Qualidade Total, particularmente, o Método 5S em forma de baldes coloridos e descarte solene dos desenhos que representem a desorganização. Ambos destacam-se pela sua criatividade e caráter inusitado da mescla de elementos, construindo métodos de abordagem insólitos a partir de aspectos que fazem parte do repertório cotidiano dos seus clientes.

As tecnologias gerenciais também estão presentes, sem ritualização, no modo de atuação de Eduardo, personal trainer e Marta, personal stylist. No caso de Eduardo, a tecnologia de gestão utilizada são as diferentes planilhas que ele elabora para cada cliente; destacando-se a "Planilha de Momentos UAU!17", ou seja, momentos considerados extraordinários vivenciados e relatados pelos clientes de Eduardo sobre os efeitos do seu trabalho. Ela pode ser considerada uma planilha inusitada, pois tentar mensurar algo tido como intangivel e que ao fazer os registros desses momentos extraordinários, Eduardo, consegue mensurar os efeitos sociais de seu trabalho. Na lista de pontos fracos e fortes sobre o tipo físico que a personal stylist, Marta faz com seus clientes para determinar que tipo de roupa é mais indicada para disfarçar as imperfeições e ressaltar os pontos positivos, por ela considerados, do corpo dos seus clientes. Por meio desta planilha Marta mostra didaticamente que suas clientes podem estar bem

\footnotetext{
17 Eduardo gosta muito dessa expressão, pois ele fez um workshop, nos EUA, com o guru da administração (atendimento ao cliente) Tom Peters, e a referida expressão é muito utilizada por Tom Peters que inclusive lançou um livro com esse nome "A busca do UAU" (1997).
} 
Mercado de serviços pessoais: uma análise antropológica das técnicas gerenciais e sua relação com a intimidade | Maria Luisa Célia Escalona de Dios

vestidas independentemente do tipo físico, se seguirem as regras e objetivos por ela (Marta) estabelecidas na planilha.

A gestão, parafraseando Gaulejac (2007, p. 64) é a construção de um sistema de interpretação do mundo social, que por oferecer uma ordem de valores e crenças, ou seja, uma visão de mundo provoca no indivíduo uma falsa sensação de poder e controle sobre si. Dito de outra forma, a gestão e suas técnicas gerenciais tornam-se uma forma de conexão do indivíduo com o mundo e com ele mesmo, que procura aprimorar e racionalizar o corpo, a mente, o tempo, a saúde, a subjetividade e os relacionamentos com o intuito de transformar as experiências da vida em utilitárias, eficientes e bem sucedidas. Assim, os personals são mediadores culturais (BOURDIEU, 2000 e VELHO e KUSCHNIR, 2001) que de maneiras variadas levam a linguagem gerencial para dentro da intimidade dos clientes. Deste modo, as técnicas gerenciais vão parar dentro do guarda-roupa, nas práticas espirituais, no estilo de vestir, na maneira de mensurar os resultados de exercícios físicos, ou seja, para a vida dos clientes dos personals.

Atualmente vivemos a era do neoliberalismo, que além de ser um conjunto de politicas e uma ideologia, segundo Fridman (2019), é também uma forma de construir-se a si mesmo em que a busca de autonomia e responsabilização individual se sobrepõe em relação às outras instâncias da vida. O autor ainda acrescenta que uma pessoa na era neoliberal tem que tratar a si mesmo como um empresário trata seus ativos. O modo como os personals utilizam as técnicas gerenciais em relação aos seus clientes, remete ao que Foucault (2008, p. 48) identificou como tecnologias do eu, a saber:

tecnologías del yo, que permiten los individuos efectuar, por cuenta propia o con la ayuda de otros, cierto número de operaciones sobre su cuerpo y su alma, pensamientos, conducta, o cualquier forma de ser, obteniendo así una transformación de sí mismos con el finde alcanzar cierto estado de felicidad, pureza, sabiduria o inmortalidad (FOUCAULT, 2008, p. 48)

Deste modo, as técnicas gerencias podem ser entendidas como tecnologias do eu. Ao utilizá-las junto aos clientes, os personals são veículos na construção de uma subjetividade em sintonia com os tempos atuais, ou seja, indivíduos autônomos, autogerenciáveis. Tendo em vista que, uma 
Mercado de serviços pessoais: uma análise antropológica das técnicas gerenciais e sua relação com a intimidade | Maria Luisa Célia Escalona de Dios

pessoa para viver em tempos neoliberais tem que ser empreendedora, investindo em si mesmo, tratando a si esmo como se ela fosse uma empresa. Em suma, nada mais representativo dos tempos atuais que tratar-se como empreendedor de si mesmo (BARBOSA, 2001), utilizando as técnicas gerenciais para o gerenciamento de si. 
Mercado de serviços pessoais: uma análise antropológica das técnicas gerenciais e sua relação com a intimidade | Maria Luisa Célia Escalona de Dios

\section{Referências}

ALVES, Giovanni. Reestruturação Produtiva e Trabalho não neo-liberal no Brasil:precarização do trabalho e redundancia salarial. Revista Katálysis, v. 12 , p. 188-197, Jul/Dez 2009. http://dx.doi.org/10.1590/S141449802009000200008.

ANTUNES, Ricardo. Adeus ao trabalho? São Paulo: Cortez, 1995.

ANTUNES, Ricardo. Os sentidos do trabalho.Ensaios sobre a aformação e negação do trabalho. $2^{\circ}$ Edição. ed. São Paulo: Boitempo Editorial, 2000.

ANTUNES, Ricardo. As configurações do trabalho na sociedade capitalista. Revista Katálysis, v. 12, Jul/Dez 2009. https://doi.org/10.1590/S141449802009000200001.

BARBOSA, Átila Magno Silva. O empreendedor de si mesmo e a flexibilização no mundo do trabalho. Revista de Sociologia Politica, v. 19(38), p. 121140, 2001. https://doi.org/10.1590/S0104-44782011000100008.

BOLTANSKI, Luc. Les Cadres.La formation d'un groupe social. Paris: Editions Minuit, 1982.

BOLTANSKI, LUc; CHIAPELLO, Ėve. O novo espirito do capitalismo. Tradução de Ivone C. Benedetti. São Paulo: WMF Martins Fontes, 2009.

BOURDIEU, Pierre. La distinción.Critério y bases sociales del gusto. $2^{\circ}$ edição. ed. Buenos Aires: Tauros, 2000.

BOURDIEU, Pierre. A produção da crença.Contribuição para uma economia dos bens simbólicos. São Paulo: Zouk, 2002.

BOURDIEU, Pierre. Questões de Sociologia. Lisboa: Fim de Século, 2003.

BOURDIEU, Pierre. O poder simbólico. Tradução de Fernando Thomaz. Rio de Jnaeiro: Bertrand Brasil, 2004.

BOURDIEU, Pierre.; MICELI, Sérgio. A economia das trocas simbólicas. 6 edição. ed. São Paulo: Perspectiva, v. Coleção Estudos,20, 2005.

BOUSSARD, Valérie. Sociologie de la gestion.Les faiseurs de performance. Paris: Belin, 2008.

CERTO, Samuel. C.; PETER, John. P. Administração estratégica. $2^{\circ}$. ed. São Paulo: Pearson Education do Brasil, 2005.

CHIAPELLO, Ėve.; GILBERT, Patrick. Sociologie des outils de gestion. Paris: La Découverte, 2013. 
Mercado de serviços pessoais: uma análise antropológica das técnicas gerenciais e sua relação com a intimidade | Maria Luisa Célia Escalona de Dios

DONADONE, Júlio. Os hunos já chegaram! Dinâmica organizacional, difusão de conceitos gerenciais e atuação das consultorias. São Paulo: USP, 2001.

DRUCKER, Peter F. The practice of management. New York: Harper Collins, 2010.

FALCONI, Vicente. Controle da Qualidade Total ( no estilo japonês). $3^{\circ}$. ed. Rio de Janeiro: Bloch, 1992.

FOUCAULT, Michel. História da Sexualidade.O cuidado de si. $8^{\circ}$ edição. ed. Rio de Janeiro: Edições Graal, v. 3, 2005.

FOUCAULT, Michel. O sujeito e o Poder. In: L.DREYFUS, H.; RABINOW, M. Foucault: uma trajetória filosófica para além do estruturalismo e da hermenêutica. Rio de Janeiro: Forense Universitária, 2010.

FOUCAULT, Michel. Tecnoligias del yo y otros textos afines. Buenos Aires: Paidós, 2008.

FRIDMAN, Daniel. El sueño de vivir sin trabajar.Una sociologia del emprendedorismo,la autoayuda finaciera y el nuevo indivíduo del siglo XXI. Buenos Aires: Siglo Veintiuno Editores, 2019.

GAULEJAC, Vicente. Gestão como doença social: ideologia, poder gerencialista e fragmentação social. Aparecida: Ideias \& Letras, v. Coleção Manegement 4, 2007.

HARVEY, David. Condição Pós- Moderna: Uma pesqusia sob as origens da mudança cultural. 12Edição. ed. São Paulo: Edições Loyola, 2003.

IRELAND, R. Duane.; HOSKISSON, Robert. E.; HITT, Michael. A. Administração Estratégica. 10 . ed. São Paulo: Cengage Learning, 2014.

LEIRIA, Jerônimo; SOUTO, C. Fernando; SARATT, Newton. Terceirização passo a passo: o caminho para a administração publica e privada. Porto Alegre: SAGRA DC Luzzato, 1992.

LERIA, Jerônimo; SARATT, Newton. Terceirização: uma alternativa de flexibilidade empresarial. São Paulo: Gente, 1995.

LEITE, Elaine da S.; MELO, Natália M. E. Uma nova noção de empresário:a naturalização do "empreendedor". Revista de Sociologia e Politica, Curitiba, v. 16 n.31, p. 35-47,2008. https://doi.org/10.1590/S010444782008000200005

LÉVI-STRAUSS, Claude. O pensamento selvagem. $5^{\circ}$. ed. Campinas: Papirus, 1989. 
LÉVI-STRAUSS, Claude. A eficácia simbólica. In: LÉVI-STRAUSS, C. Antropologia Estrutural. Rio de Janeiro: Tempo Brasileiro, 2003. Cap. Capitulo X, p. 215-236.

LÉVI-STRAUSS, Claude. Antropologia Estrutural. Rio de Janeiro: Tempo Brasileiro, 2003.

LÉVI-STRAUSS, Claude. O feiticeiro e sua magia. In: LÉVI-STRAUSS, C. Antropoogia Estrutural. Rio de Janeiro: Tempo Brasileiro, 2003.Capitulo IX, p. $193-213$.

MAUSS, Marcel. Sociologia e Antropologia. São Paulo: Cosac \& Naif, 2003. MAUSS, Marcel. Técnicas do corpo. In: MAUSS, M. Sociologia e Antropologia. São Paulo: Cosac \& Naif, 2003. Cap. Sexta parte, p. 399-422.

MELO, Natália. M. E. SEBRAE e o Empreendedorismo: oriegem e desenvolvimento. Dissertação de mestrado. UFSCAR: São Carlos, 2008.

PEIRANO, Mariza. 0 dito e o feito. Ensaios de antropologia dos rituais. Rio de Janeiro: Relume Dumará, 2002.

PEIRANO, Mariza. Rituais ontem e hoje. Rio de Janeiro: Jorge Zhaar, 2003.

RIFKIN, Jeremy. O fim dos empregos: o declínio inevitavel dos níveis dos empregos e a redução da força global de trabalho. Tradução de Ruth Gabriela Bahr. 1Edição. ed. São Paulo: Makron Books, 1995.

SENNETT, Richard. A corrosão do caráter.Consequências pessoais do trabalho no novo capitalismo. Tradução de Marcos Santarrita. $11^{\circ}$ edição. ed. Rio de Janeiro: Editora Record, 2006.

SENNETT, R. A cultura do novo capitalismo. Tradução de Clóvis Marques. Rio de Janeiro: Record, 2006a.

TESSARI, Cláudia. Anuário Industrial da Gazeta Mercantil, São Paulo, v. $1,2001$.

VELHO, G.; KUSCHNIR, K. Mediação, Cultura e Política. Rio de Janeiro: Aeroplano, 2001.

WEBER, M. Ensaios de Sociologia. 5edição. ed. Rio de Janeiro: LTC, 1982.

ZELIZER, V. La negociación de la intimidad. Buenos Aires: Fondo de Cultura Economica, 2009. 